\title{
Incidence of heifer mastitis and identification of major associated pathogens in dairy farms at wolaita soddo town, southern Ethiopia
}

\begin{abstract}
The replacement stock is one of the vital parts of dairying no dairy farmer can afford to overlook. Although heifers, as calves and as primiparae, have been thought of as a group as free of mastitis, many studies indicated that clinical mastitis (CM) was even higher in heifers during calving than multifarious cows. The present longitudinal study was conducted to assess the incidence of heifer mastitis, to isolate and identify the causative pathogens and their susceptibility profile against some antimicrobials. By using convenience sampling method a total of 28 heifers from two sampling point (large scale dairy farms 1 and small holders' cooperative dairy farms 2 were followed and sampled throughout study period. Physical examinations of udder and milk and California mastitis Test (CMT) was applied detect clinical and subclinical mastitis, respectively. Accordingly, a total of 112 quarters were examined. The incidence of mastitis per gland at risk was $60.7 \%$ and the spontaneous cure rate of infected quarters was $24.18 \%$. Incidence of heifers intramammary infections (IMI) in the study area was highest at calving (35.7\%). Infection per quarter revealed that $43 / 112(38.3 \%)$ of which $9 / 43(20.9 \%)$ quarters were clinical and $34 / 43(79.0 \%)$ quarters were sub clinical type of mastitis. However, 5(4.5\%) of the total quarters examined were blind. Incidence of mastitis in rear quarters was significantly higher than front quarters $(\mathrm{p}<0.05)$. The result revealed that high milk producing heifers (HF and jersey) were significantly susceptible to mastitis $(\mathrm{p}<0.05)$. The univariate logistic regression showed that breed, age, practice of milking mastitic cow last, housing nature, hand wash before and in between milking and udder hygiene had significant effect on the prevalence of subclinical mastitis. Staphylococcus aureus (30.3\%), Coagulase negative Staphylococci (CNS) [15.2\%] and Streptococcus agalactiae (15.2\%) were the predominant bacteria. Relatively most of the isolates are susceptible to chloramphenicol, gentamycin, ciprofloxacin and kanamycin but resistant to penicillin. High incidence of heifer mastitis especially occurs as a subclinical type and in high milk producing breeds and older age groups in this area. Serious attention should be given to heifers prepartum udder health because it is most essential for control and prevention of heifer mastitis.
\end{abstract}

Keywords: antimicrobials susceptibility, bacterial pathogens, dairy farms, heifer mastitis, longitudinal, risk factors
Volume 5 Issue 5 - 2017

\author{
Ashenafi Kiros Wubshet,' Tesfaye Sisay \\ Tesema, ${ }^{2}$ Muuz Gebru sahile, ${ }^{3}$ Biniam \\ Tadesse Derib,' Aklilku Feleke Haile, ${ }^{4}$ Hagos \\ Asgedom Wedeabyezgi' \\ National Animal Health Diagnostic and Investigation Centre, \\ Ethiopia \\ ${ }^{2}$ Addis Ababa University, Institute of Biotechnology \\ Mekelle University, College of Veterinary Medicine, Ethiopia \\ ${ }^{4}$ Addis Ababa University, College of Veterinary Medicine and \\ Agriculture, Ethiopia
}

Correspondence: Ashenafi Kiros wubshet, National Anima Health Diagnostic and Investigation Centre, Sebeta, Ethiopia, Te +251910017931,Email nafikw@gmail.com

Received: November 27, 2016 | Published: July 27, 2017

\section{Background}

Rearing calves and heifers as replacement milkers, is a serious business and the replacement stock are one aspect of dairying no dairy farmer can afford to overlook. In brief, while it is true that the milking herd generates the income, calves and heifers are just as valuable to the dairy's future as the current milking herd. Traditionally heifers, as calves and as primiparae, have been thought of as a group as free of mastitis since without appreciable lacteal secretion, there is reduced nutrient fluid available to support growth of intramammary pathogens. ${ }^{3}$ However, mastitis during development of the mammary gland and in early lactation is hypothesized to adversely affect their milk production and udder health, leading to considerable economic losses for dairy farms. ${ }^{4}$

Heifers (2yrold primiparous cattle) have a high incidence of clinical mastitis $(\mathrm{CM})$ in the peripartum period relative to older animals in herds. Studies reported a high incidence of CM and IMI in first-calving heifers immediately following calving. ${ }^{5}$ Most studies of intramammary infections (IMI) in heifers have been performed as single surveys to determine the prevalence of IMI at, or close to, parturition or have compared IMI several months before parturition with IMI at parturition. ${ }^{2}$ The prevalence of intramammary infections (IMI) in non-lactating and freshly calved heifers has been the focus of study in many countries. ${ }^{6}$

Antimicrobials are used frequently for treatment and prevention of mastitis. To successfully control mastitis and to avoid potential problems associated with bacterial resistance and treatment failure, it is important to be aware of antimicrobial resistance characteristics of mastitis pathogens. ${ }^{7}$ Although many farmers and veterinarians in the study area have observed heifers calving with nonfunctional quarters, clinical mastitis, or elevated somatic cell counts. No investigation on udder health of dairy heifers and the risk factors for heifers mastitis was carried out in the study area. However, there is only one study from Ethiopia by Siraj et al. ${ }^{8}$ that has been published with regard to bacterial pathogens and udder infection dynamics during the early lactation period in primiparous cows. Hence, large scale risk factor 
analysis is needed to quantify heifers mastitis as well as to identify associated risk factors.

Knowledge of when heifers become infected with different mastitis pathogens is a prerequisite for establishing control strategies. Furthermore, knowledge regarding the persistence of IMI with different pathogens is necessary to make decisions regarding antibiotic treatment. In addition to understanding the pattern of disease, it is necessary to measure its long-term effects on udder health and production to allow a cost-benefit analysis of any control programme. Without such concrete knowledge however, designing control programmes may be at best only guess-work and the quantification of dairy heifer mastitis data in the study area in particular and in Ethiopia at large is needed to get some insight on their overall negative economic implications. Therefore, the objectives of this study were to assess the incidence of heifer mastitis in dairy farms at Wolaita Soddo town, to identify potential risk factors for heifer mastitis, to isolate and identify bacteria causing heifer mastitis in line to evaluate the sensitivity of the bacterial isolates for different antibacterial agents.

\section{Materials and methods}

\section{Study design}

A longitudinal type of study was conducted from November 2012 to April 2013 to determine the incidence of heifer mastitis, isolate and identify bacterial species and evaluate antimicrobial sensitivity in the study area. A onetime questionnaire survey was conducted on the selected farms. The herds were selected on the availability of heifers and the willingness of the owners to cooperate.

\section{Study animals}

The study animals were heifers in between two months before and after calving in the study areas. Three breed of heifers (cross breed, $\mathrm{HF}$ and jersey) were included in the study. Total of 28 heifers from 15 dairy farms in three sub cities namely (Arada, Mehal and Merkato) of 7 kebelles in Wolaita Sodo town were selected conveniently based on the availability of heifers and the willingness of the farm owners.

\section{Sampling techniques}

Purposive sampling technique was applied in this study i.e., all heifers in between two months before and after calving was included in the study. The clinical investigations of each heifer were started 8 weeks before the anticipated calving date. Upon enrollment, the heifers were given identification number and their age and breed in each herd. The heifers were immobilized and secretion samples for microbiological tests were taken from open udder quarters. The assessment of open or closed udder quarters was done using the method described by Williamson. ${ }^{9}$ It involves applying light pressure to the teat sinus by using a gentle milking action with the thumb and index finger, allowing the contents to slip upward within the teat. If the pressure applied by this action results in a drop of secretion at the orifice, the teat is classified as being 'open', otherwise as 'closed'. Only open quarters were sampled. Due to the small volume of secretion present in most glands, foremilk secretion was not discarded strictly before collection of the sample ante partum. Sampling was repeated until parturition at 4 week intervals. After calving, duplicate samples of quarter foremilk were collected for bacteriological culturing in the first week and in intervals of 4weeks up to mid lactation. During each visit, the heifer management, housing, and sanitation situations were also observed. Health issues of the heifer occurred out of the visiting time was communicated by the owners with the investigator.

\section{Data collection}

Questionnaire survey: A semi-structured questionnaire was developed and pre-tested, and all information relating to the study objectives was recorded. The questionnaire survey was designed to provide data on critical factors that might be associated with heifer mastitis at the farm and individual level. Data were collected on potential risk factors for the occurrence of mastitis in heifers based on face-to-face personal interview with the farm manager or senior worker by the investigators. The animal level factors such as herd size, presence of teat lesion, teat blindness, body condition and breed difference was recorded. The farm level factors such as housing types, farm hygiene, barn floor status, type of milking method, use of towels, milking sequences and hygiene was recorded. Udder and milk abnormalities (injuries, blindness, tick infestation and indurations, swelling, milk clots, abnormal secretion, etc.) were also recorded.

Milk sample collection: Milk sample were collected according to the procedure recommended by Quinn PJ et al. ${ }^{10}$ Strict aseptic procedures will be followed when collecting milk samples in order to prevent contamination with microorganisms present on the skin udder and teats, on the hands of samplers and on the barn environment. Teat ends were cleaned and disinfected with ethanol $(70 \%)$ before sampling. Strict foremilk (first jets) was discharged to reduce the number of contamination of teat canal 28. Sterile universal bottle with tight fitting cups were used. The universal bottle was labeled with permanent marker before sampling. To reduce contamination of teat ends during sample collection, the near teats will be sampled first and then followed by the far ones. The collecting universal bottle was held as horizontal as possible and by turning the teat to the near horizontal position; $10 \mathrm{ml}$ of milk sample was collected from each quarter of the udder into the universal bottle. After samples were collected, they were properly packed and transported in an ice box to the Wolaita Sodo diagnostic veterinary laboratory. Samples that were not immediately processed were refrigerated at $+4^{\circ} \mathrm{C}$ for 24-72hours. Samples to be processed after 3 days were kept in a refrigerator below $-20^{\circ} \mathrm{C}$. All collected milk samples were examined for mastitis using California mastitis test. (CMT) was carried out using the method described by Quinn PJ et al. ${ }^{10}$

Bacterial isolation and identification: Samples were supposed to be examined for the presence of common mastitis causing bacteria. The bacteriological examination was carried out following standards methods of Quinn PJ et al. ${ }^{11}$ Culture status of milk samples was defined according to the procedures recommended by the German Veterinary Association. ${ }^{12}$ A milk sample was defined as being contaminated if $>$ 3 bacterial species were isolated.

Antimicrobial sensitivity testing: The antimicrobial resistance profiles of the bacterial isolates were determined using Kirby-Bauer-disk diffusion method.$^{10}$ The antibiotic impregnated disks that used for the test were Vancomycin, Streptomycin, Chloramphenicol, Ciprofloxacin, Kananamycin, penicillin, Gentamycin and Tetracycline. Disks were stored under refrigeration at $4^{\circ} \mathrm{c}$ to ensure maintenance of their potency. Well isolated bacterial colonies of the same morphologic type were inoculated into $7 \mathrm{ml}$ of Tryptophan soya broth and incubated at $37^{\circ} \mathrm{C}$ for 8 hours until turbidity is seen and were compared to the $0.5 \mathrm{McF}$ arland standards. Müeller-Hinton Agar for less fastidious bacterial isolates and 5\% sheep blood added Müeller-Hinton Agar for streptococcus species isolates were used as planting medium. Fifteen minutes after inoculation of the plates, the antibiotic impregnated disks were applied on the surface of inoculated plates with sterile forceps. All the disks were gently pressed down onto the agar with 
forceps to ensure complete contact with the agar surface. The plates were inverted and then incubated aerobically for 18 hours at $37^{\circ} \mathrm{C}$. The diameters of the zone inhibition were measured to the nearest whole millimeter using the transparent rule. Zone of inhibition for individual antimicrobial agents were translated into susceptible, intermediate and resistant. Categories by referring the recommended ${ }^{13}$ interpretative standard.

\section{Data management and statistical analysis}

All collected data in Microsoft excel spread sheet were transferred to SPSS version 20.0 for analysis. P-Value $<0.05$ was considered significance. The CMT screening test data obtained during the longitudinal period of study were analyzed to determine the incidence of heifer mastitis in the study area. ${ }^{14}$ Significance of risk factors on the incidence of mastitis in heifers was tested through chi-square $\left(\chi^{2}\right)$ test to check presence of significant association between CMT positive and risk factors. Logistic regression and odds ratio was applied to find out the magnitude of association between the selected factors and mastitis.

\section{Results}

\section{Gland infection dynamics}

Of the total 28 heifers $17(60.7 \%)$ of the glands were found infected. A total of 112 quarters from 28 heifers were investigated for clinical and subclinical mastitis (based on r CMT screening) during the study period. The incidences of mastitis over 28 glands examined during the entire period of study were $7.1 \%, 35.7 \%, 14.3 \%$ and $3.6 \%$ at precalving, calving, early lactation and mid lactation, respectively (Table 1). Incidence of mastitis during the study period had significant variation $(p<0.05)$, the highest incidence observed being at calving. The percentage of CMT positive glands that remained positive after a month and the percentage of CMT negative glands that remained negative after a month were $76 \%$ and $86 \%$, respectively (Table 2). The spontaneous cure rate of infected quarters was $24 \%$ which was found to be significantly affected by management practices. The genetic association of susceptibility to mastitis among the three breeds was made. The result revealed that high milk producing heifers (HF and jersey) were significantly susceptible to mastitis $(\mathrm{p}<0.05)$.

Table I Association of incidence of mastitis among breeds of heifers

\begin{tabular}{lllll}
\hline \multicolumn{5}{l}{ Mastitis status breeds } \\
\hline N & Cross breed & HF & Jersey \\
Positive & 17 & $3(10.7 \%)$ & $8(28.6 \%)$ & $6(21.4 \%)$ \\
Negative & II & $7(25.0 \%)$ & $3(10.7 \%)$ & I $(3.06 \%)$ \\
Total & 28 & 10 & II & 7 \\
X2 $=6.455 \mathrm{df}=2 \mathrm{p}=0.04$ & &
\end{tabular}

\section{Quarter-level incidence of heifer mastitis}

Infection per quarter revealed that $43 / 112(38.3 \%)$ were mastitis positive of which $9 / 43(20.9 \%)$ quarters were affected with clinical and $34 / 43(79.0 \%)$ quarters were affected with sub clinical type of mastitis. However, $5(4.5 \%)$ of the total quarters examined were blind. The overall infection was higher in left rear (39.5\%) followed by $25.6 \%$, $18.6 \%$ and $14 \%$ in right rear, front left and front right, respectively
.The overall difference was statistically significant with $\mathrm{P}<0.05$. The Figure 1 showed that precalving quarter samples were taken a month before individual calving date. The prevalence of infected quarter precalving was $14 \%, 53.6 \%, 25 \%$ and $7 \%$ at calving, early lactation and mid lactation, respectively. There was no significant difference $(\mathrm{P}>0.05)$ among quarter level infection among the period of study. However, relatively highest incidence was recorded at calving. Furthermore, association was made between the breed of cows, which may have a unique udder conformation, with that of quarter level heifer mastitis. The Jersey and HF were found to be highly affected on their RL quarter compared to the other quarters. However, all the four quarters of the cross breeds were almost equally affected.

Table 2 Changes in gland infection status between CMT positive and negative quarters

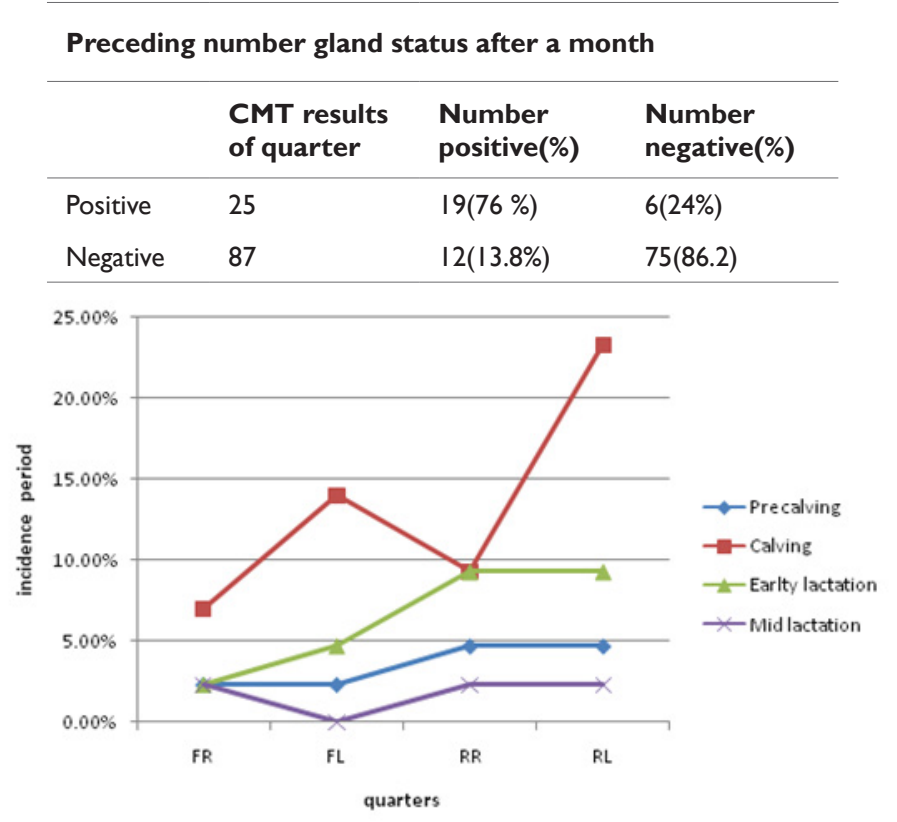

Figure I Quarter level incidence of mastitis in different period of the study. $F R$, right front quarter; FL, left front; $R R$, right rear; $R L$, right rear

\section{Bacterial isolates}

As shown in Table 3 a total of 66 bacterial isolates were identified from milk samples. The corresponding isolation rates of bacterial spp during clinical and subclinical heifer mastitis were Staphylococcus aureus 2(33.3\%) and 18(30.5\%), Staphylococcus epidermidus $1(16.7 \%)$ and 6(10.1\%), Staphylococcus intermidius $0(0 \%)$ and $3(3.4 \%)$, Streptococcus agalactiae $0(0 \%)$ and $10(16.9 \%)$, Streptococcus dysagalactiae $0(0 \%)$ and 4(6.8\%), Streptococcus uberis $0(0 \%)$ and 5(13.6\%), Micrococcus spp $0(0 \%)$ and 3(3.4\%), Escherichia coli $2(33.3 \%)$ and 5(13.6\%), Actinomyces pyogenes $0(0 \%)$ and $1(1.9 \%)$, Corynebacterium bovis $0(0 \%)$ and 2(6.8), Klebsiella pneumoniae $1(16.7 \%)$ and $2(6.8 \%)$ and Bacillus cereus $0(0 \%)$ and $1(1.9 \%)$. The relative prevalence rates of various bacterial species isolated from the clinical and sub-clinical cases per individual quarter showed single and mixed udder infections by different bacterial isolates. Staphylococcus aureus were the major pathogens isolated from 20 (48.7\%) quarters, out of which 19.5\%, 7.3\%, $4.9 \%$ and $2.4 \%$ share with Streptococcus agalactiae, Staphylococcus epidermidus, and Staphylococcus intermidius and Micrococcus spp, respectively. Association between the incidence of major pathogens 
and the period of study was made. The incidence of predominant pathogen in the period of study had significant difference $(\mathrm{p}<0.05)$. The highest incidence of Staphylococcus aureus, Escherichia coli, and Streptococcus agalactiae were atcalving. Lower incidences of these pathogens were observed during pregnancy. The high incidence of Staphylococcus aureus mastitis in heifers poses the greatest threat to production. Relative higher incidences of coagulase negative Staphylococcus aureus (CNS) were during pregnancy (Figure 2).

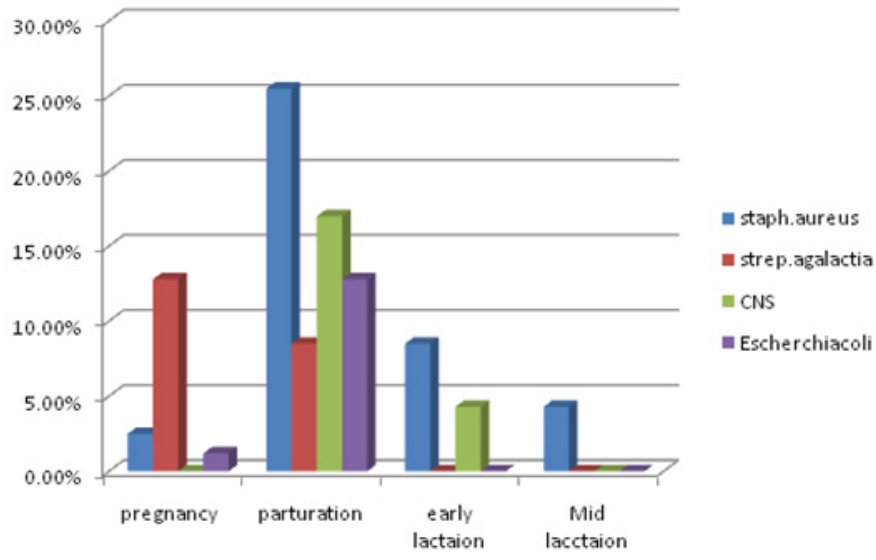

Figure 2 Incidence of bacterial isolates in percent with period of infection.

Risk factors associated with incidence of heifer mastitis

Some risk factors for heifer mastitis (clinical and subclinical) at herd and heifer-level have been identified. The result of univariate logistic regression revealed that the overall incidence of heifer mastitis was significantly affected by breed, age and tick infestation on teats $(p<0.05)$. The incidence of heifer mastitis was significantly higher in jersey breed (85.7\%), in heifers greater than $18(72.2 \%)$ and in those heifers with high tick infestation (84.6\%) (Table 4). When those factors with p-values less than 0.25 were fitted in the multivariate model, only breed and age had significant effect on heifer level incidence $(\mathrm{p}<0.05)$. Jersey heifers were more affected by mastitis than others $(\mathrm{OR}=14)$ and heifers in age group greater than 18 are more susceptible than the younger one $(\mathrm{OR}=13.3)$. According to the result of univariate logistic regression, from the farm attributes considered as potential risk factors, only the management practice, practice of milking mastitic cow last, housing nature, hand wash before and in between milking had significant effect on herd level prevalence of mastitis. Farm which practiced milking mastitic cow at last were less affected by mastitis $3(30 \%)$ than which does not do such practice 14(77. 8\%) (Table 5). Management practices $(\mathrm{OR}=0.030, \mathrm{P}=0.001)$ had significant effect on herd level prevalence of mastitis. Prevalence of mastitis was higher in intensive farm management system $15(88.2 \%)$ than those in semi intensive management system $2(18.2 \%)$.

\section{In Vitro antibiotic sensitivity profile of bacterial isolates}

As described in table 6 only 37 of present isolates were exposed to antimicrobial susceptibility testing. In all of the tested bacterial isolates, 80 to $100 \%$ of the tested were susceptible to chloramphenicol, gentamycin and ciprofloxacin but resistance to penicillin. Isolates of S.Aureus showed moderate to very high susceptibility for vancomycin (70\%), Streptomycin $(70 \%)$ and kanamycin $(80 \%)$ but very high to moderate resistance to penicillin $(100 \%)$ and tetracycline (50\%). Except to penicillin (66.6\%), isolates of S.intermidius and $S$. epidermidis were susceptible to all the antimicrobials tested. Strep. agalactiae isolates showed strong resistance to streptomycin $(66.6 \%)$ and vancomycin (100\%). Strep.uberis isolates were strongly susceptible for all antimicrobials tested except Penicillin (100\%) and vankomycin (100\%).Isolates of E.coli were susceptible for most of tested antimicrobials except vancomycin $(100 \%)$ and streptomycin $(100 \%)$, tetracycline $(50 \%)$. Isolate B.cereus was resistant to penicillin and vancomycin.

Table 3 Prevalence of bacterial pathogens during the entire study period

\begin{tabular}{|c|c|c|c|}
\hline \multicolumn{4}{|c|}{ Bacterial isolates no. \& \% bacterial isolates } \\
\hline Examined animal & Clinical $(\mathbf{N}=\mathbf{2 8})$ & Subclinical $(\mathbf{N}=6)$ & Mastitis(N=60) \\
\hline Staphylococcus aureus & $20(30.3 \%)$ & $2(33.3 \%)$ & $18(30.5 \%)$ \\
\hline Staphylococcus epidermidus & $7(10.6 \%)$ & $\mathrm{I}(\mathrm{I} 6.7 \%)$ & $6(10.1 \%)$ \\
\hline Staphylococcus intermidius & $3(4.5 .7 \%)$ & --- & $3(3.4 \%)$ \\
\hline Streptococcus agalactiae & $10(35.7 \%)$ & --- & $10(16.9 \%)$ \\
\hline Streptococcus dysagalactiae & $4(14.2 \%)$ & --- & $4(6.8 \%)$ \\
\hline Streptococcus uberis & $5(17.9 \%)$ & --- & $5(13.6 \%)$ \\
\hline Micrococcus spp & $3(10.7 \%)$ & --- & $3(3.4 \%)$ \\
\hline Escherichia coli & $7(25 \%)$ & $2(33.3 \%)$ & $5(\mid 3.6 \%)$ \\
\hline Actinomyces pyogenes & I (3.5\%) & --- & $\mathrm{I}(\mathrm{I} .9 \%)$ \\
\hline Corynebacterium bovis & $2(7.1 \%)$ & --- & $2(6.8 \%)$ \\
\hline Klebsiella pneumoniae & $3(10.7 \%)$ & $\mathrm{I}(16.7 \%)$ & $2(6.8 \%)$ \\
\hline Bacillus spp. & I (3.5\%) & --- & $\mathrm{I}(\mathrm{I} .9 \%)$ \\
\hline Total isolates & 66 & 6 & 60 \\
\hline
\end{tabular}


Table 4 Result of univariate logistic regression at heifer level

\begin{tabular}{lcllll}
\hline Factor categories & $\mathbf{N}$ & No of positive (\%) & P-value & OR 95\% & Confidence OR \\
\hline Breed & & & & & \\
Cross breed & 10 & $3(30)$ & & & \\
HF & 11 & $8(72.7)$ & 0.059 & 6.2 & $0.94-41.4$ \\
Jersey & 7 & $6(85.7)$ & 0.039 & 14 & $1.14-172.7$ \\
Age & & & & & \\
$>I .8$ & 22 & $16(72.7 \%)$ & 0.03 & 13.3 & $1.28-138.84$ \\
$<1.8$ & 6 & $1(16.7 \%)$ & & & \\
Tick Infestation & & & & & \\
Yes & 13 & $11(84.6)$ & 0.024 & 0.121 & $0.20-0.753$ \\
No & 15 & $6(40.0)$ & & & \\
Presence Teat Lesion & & & & & \\
Yes & 9 & $8(88.9)$ & 0.059 & 0.113 & $0.12-1.084$ \\
No & 19 & $9(47.4)$ & & & \\
\hline
\end{tabular}

$\mathrm{N}$, number of observation

Table 5 Result of univariate logistic regression at herd level

\begin{tabular}{|c|c|c|c|c|c|c|}
\hline Factors & Categories & $\mathbf{N}$ & No of positives\% & $P$ value & OR 95\% & $\mathrm{Cl}$ of OR \\
\hline \multirow{2}{*}{ Management Practice } & Intensive & 17 & 15(88.2) & 0.001 & 33.8 & $4.02-283.2$ \\
\hline & Semi intensive & 11 & $2(18.2)$ & & & \\
\hline \multirow{2}{*}{ Heifer Milking Practice } & before cow & 16 & $10(62.5)$ & 0.823 & 1.2 & $0.26-5.05$ \\
\hline & after cow & 12 & $7(58.3)$ & & & \\
\hline \multirow{2}{*}{ Milking practice of Mastitis Cow } & Yes & 10 & $3(30)$ & & & \\
\hline & No & 18 & I4 (77. 8) & 0.019 & 0.12 & $0.21-0.705$ \\
\hline \multirow{2}{*}{ Towel use } & Yes & 7 & $2(28.6)$ & & & \\
\hline & No & 21 & I5(7|.4) & 0.058 & 0.16 & $024-1.063$ \\
\hline \multirow{2}{*}{ Previous Mastitis problem } & Yes & 16 & $10(62.5)$ & 0.823 & 1.2 & $0.26-5.5$ \\
\hline & No & 12 & $7(58.3)$ & & & \\
\hline \multirow{2}{*}{ Knowledge of dry cow therapy } & Yes & 10 & $7(70)$ & & & \\
\hline & No & 18 & $10(55.6)$ & 0.456 & 1.9 & $0.36-9.64$ \\
\hline \multirow{2}{*}{ Application of dry cow therapy } & Yes & 10 & $7(70)$. & & & \\
\hline & No & 18 & $10(55.6)$ & 0.823 & 0.823 & $0.144-4.660$ \\
\hline \multirow{2}{*}{ Hand wash } & Yes & 6 & $I(16.7)$ & & & \\
\hline & No & 22 & $16(72.7)$ & 0.03 & 0.075 & $0.007-0.78 \mid$ \\
\hline \multirow{2}{*}{ Udder wash } & Yes & 6 & $2(33.3)$ & & & \\
\hline & No & 22 & $15(68.2)$ & 0.137 & 0.233 & 0.34 I.59I \\
\hline \multirow{2}{*}{ Housing nature } & Sloppy & 10 & $4(40)$ & 0.007 & 0.042 & $0.004-0.42$ \\
\hline & Leveled & 18 & $13(72.2)$ & & & \\
\hline \multirow{2}{*}{ Housing Type } & Cement & 15 & $5(33.3)$ & 0.102 & 0.256 & $0.050-1.312$ \\
\hline & Muddy & 13 & $12(92.3)$ & & & \\
\hline \multirow{2}{*}{ General hygiene } & Good & 10 & $6(60)$. & 0.954 & 0.955 & $0.196-4.64$ \\
\hline & Bad & 18 & II(6I.I) & & & \\
\hline
\end{tabular}

$\mathrm{N}$, number of observation 


\section{Discussion}

This study attempted to assess the incidence of heifer mastitis in dairy farms at Wolaita Soddo town, to identify potential risk factors for heifer mastitis, to isolate and identify bacteria causing heifer mastitis and to evaluate the sensitivity of the bacterial isolates for different antibacterial agents. The variability in incidence and prevalence of mastitis may be due to alteration of several factors mainly of management, environment and factors related to animal and to causative organism. The overall incidence of heifer mastitis (60.7\%) was comparable with Pankey JW, ${ }^{15} 46 \%$ and higher than result reported by Siraj A, ${ }^{8}$ which was $26.06 \%$. This may be due to variation in management practices, breeds of animals studied and other factors which are agreed with the suggestion of Fox $\mathrm{LK}^{3}$ indicated that management interventions at the farm level may be useful in reducing the risk of these infections.

The present study indicated that the incidence of subclinical mastitis were higher than clinical type. The result was in agreement with Roberson JR et al. ${ }^{16}$ Sub-clinical mastitis has been reported to be higher than clinical mastitis owing to the defense mechanism of the udder, which reduces the severity of the disease. ${ }^{16}$ Heifers have a lower incidence rate of clinical mastitis compared with older cows. ${ }^{17}$ The owners of small holder dairy farms in the study area were not well informed about the invisible loss from subclinical mastitis. Therefore, mastitis in primiparae can be economically detrimental for a farmer's business. This study revealed the highest incidence of heifer mastitis at calving $(35.7 \%)$ followed by early lactation. This is higher than the result reported by Oliver $\mathrm{SP}^{18}$ who showed that $19.7 \%$ of heifer mammary glands were infected at calving; however, it is lower than ${ }^{2}$ as many as half of all mammary quarters in heifers may have IMI at first parturition. Additional study by Trinidad $\mathrm{P}^{19}$ reported, as many as $97 \%$ of heifers had IMI at parturition. Highest incidence of heifer mastitis at calving in this study area was because of Poor hygiene of the calving area and absence of prepartum intramammary treatment. The reason was in agreement with previous author., ${ }^{9,20}$ Teat disinfection before calving was associated with a decreased risk of calving with an environmental pathogen intramammary infection (IMI) ${ }^{21}$ and Vaccination of heifers was successful in reducing the incidence of $S$. Aureus IMI. ${ }^{22}$

Negative quarters could remain negative for a relatively longer period compared to positive quarters. The likelihood that a quarter not infected in the preceding month could remain negative in the subsequent month was about four times higher (than the likelihood that an already infected gland could be free of infection (Table 2). This might be linked with the application of antibacterial agents before the expected date of calving which could help to reduce the incidence of mastitis during the early lactation period as Siraj $\mathrm{A}^{8}$ described. The application of antimicrobials approximately two months prepartum was reported to have reduced the incidence of intra mammary infections by $59 \%$ and treatment in the third trimester generally reduced the occurrence of new prepartum intramammary infections and persisted up to calving with cure rates ranging from 80 to $100 \%$ for Staphylococci and Streptococci, ${ }^{23}$ while cure rates during lactational therapy were approximately $50 \%{ }^{24}$

The relative high prevalence of mastitis was in left rear quarters $(39.5 \%)$. This is approximately in agreement with previous reports by Sori $\mathrm{H}^{25}$ This may be due to greater production capacity of hindquarters ${ }^{26}$ and the likelihood of fecal and environmental contamination of hindquarters. The prevalence of mastitis in right front quarter was lower (14\%) than that of ${ }^{25}(30.06 \%)$. This may be due to less prone to contamination by heifer environment. As it has shown in Figure 1 that the left quarters (FL and RL) have higher infection compared to that of the right quarters during pregnancy and calving. This might be associated with the side of the animal exposed often to the environment.

\section{Risk factors}

The current result of univariate logistic regression revealed that the overall incidence of heifer mastitis was significantly affected $(\mathrm{p}<0.05)$ by breed. The highest proportion was scored by HF and Jersey. The result is in agreement with a study by Nibret $\mathrm{M}^{7}$ in multiparous, crosses of zebu with Holstein Frisian cows were affected (71.8\%) at higher rate than zebu breeds (28.2\%). This is because higher-yielding cows have been found more susceptible to mastitis ${ }^{27}$ owing to position of teat and udder and anatomy of teat canal, making them prone to injury. ${ }^{27}$ High milk yield my also associated with lowering function of phagoacytic cells because of sever dilution.

In addition, the physical characteristics of heifer mammary secretions corresponded to the frequency of infection. ${ }^{23}$ According to univariate regression prevalence of mastitis had a significant difference $(\mathrm{P}<0.05)$ in between age groups (Table 1). The result is in agreement with a study by Bassel $\mathrm{L}^{21}$ who indicated that an increased age at calving is a significant risk factor for $S$. Aureus and environmental pathogen IMI. The risk of $S$. Aureus IMI was also affected by the amount of time the heifers were housed with older cows, and the proportion of S. Aureus infected cows in the herd. ${ }^{21}$ The incidence of mastitis was statically significant and higher in heifers kept under the intensive management system compared to heifers under the semiintensive management system. The result and reason was in line with study reported by Siraj A. ${ }^{8}$ This could be due to the restricted exercise of animals and the transmission of pathogens from infected cows to primiparae as animals were housed together. The incidence of heifer mastitis was significantly higher in heifer with udder (teat) infested with tick $(84.6 \%)$ than heifer with normal udder or teats $(40 \%)$ and $88.9 \%$ of udders showed lesion. Tick bite on udder can cause skin irritation and localized inflammatory response, which can lead to secondary bacterial infection. Another author ${ }^{24}$ added that scabs on teats can also be potential sources of S.Aureus.

\section{Bacterial isolate}

The relative prevalence rates of various bacterial species isolated from the clinical and sub-clinical cases was recorded. The pathogens that cause mastitis in multiparae are also causes of both pre and postpartum intramammary infections in heifers. ${ }^{28}$ Staphylococcus aureus were the major pathogens isolated from 20(30.3\%) quarters followed by Streptococcus agalactaiae these were less than the findings of Fox LK ${ }^{9}$ that suggest Staphylococcus aureus (44.3\%) as predominant pathogen but comparable with ${ }^{8}(27 \%)$. The predominance of Staph. Aureus in the study area might be due poor milking and management practices such as lack of effective udder washing and drying, post milking teat dip and drying, inter-cow hand washing, and disinfection in the milking routine of the area. Contamination of milkers' hands from infected quarter has been reported to easily transmit this pathogen. Other possible reasons for higher prevalence of $S$. Aureus were similar with suggestions of Bassel L, Owens $\mathrm{WE}^{21,24}$ which stated as horn flies (Haematobia irritans) are capable of transmitting $S$. Aureus induced IMI to heifers and the risk of $S$. Aureus IMI was also affected by the amount of time the heifers were housed with older cows, and the proportion of S. Aureus infected cows in the herd, respectively. 
The 10(15.2\%) isolates were CNS which are third most prevalent pathogens in primiparous Cows. The results were comparable with previous work reported by Bitew M, Almaw G, Argaw K, Mekbib $\mathrm{B}^{1,29-31}$ in cow but higher than results reported in heifers by Siraj A. ${ }^{8}$ Higher prevalence is due to lack of effective udder washing and drying, post milking teat dip and drying, inter-cow hand washing, and disinfection in the milking routine of the area. Streptococci were the second most prevalent genera. Similar results were reported from other studies in Ethiopia ${ }^{8}$ in nulliparous cow; ${ }^{1,31,32}$ in multiparous. Exposure to environmental Streptococci may occur during milking, between milking and during dry period. ${ }^{27}$ The prevalence of $E$. coli from this study was $7(10.6 \%)$ which was similar to the findings of Siraj $\mathrm{A}^{8}$ in primiparous. However, it was higher than other findings $\mathrm{s}^{5,33}$ in multifarious cows who reported 2.2, 3.9 and 3.9\%, respectively. Faeces which are common sources of $E$. coli can contaminate the premium directly or indirectly through bedding, calving stalls, udder wash water and milker's hands. ${ }^{8}$ The other bacterial species were of lesser frequency and similar distribution patterns by previous workers ${ }^{1,31,32}$ in multiparous cow in Ethiopia. The reason of variations in the preponderance of the bacterial species among the different studies is in agreement with previous suggestions. Fox $\mathrm{LK}^{2} \&$ Siraj $\mathrm{A}^{8}$ suggesting management practices in farms and the agro-climatic heterogeneity of the country.

\section{Antimicrobial sensitivity profiles}

Antimicrobials are used frequently for treatment and prevention of mastitis. To successfully control mastitis and to avoid potential problems associated with bacterial resistance and treatment failure, it is important to be aware of antimicrobial resistance characteristics of mastitis pathogens. ${ }^{7}$ Although great effort is done in mastitis prevention and education of farmers and veterinarians, mastitis treatment often does not have appropriate success since it is done without previous isolation of microorganisms', without sensitivity testing. ${ }^{34}$ Therefore antimicrobial susceptibility test is useful to carry out effective treatment because certain microorganisms are resistant to certain antimicrobials. ${ }^{35}$ The antimicrobial susceptibility tests carried out in this study indicated the existence of susceptibility and resistance by common pathogens against some of the antimicrobials. When the overall result of antimicrobials susceptibility test in the present study was compared on all isolates, chloramphenicol, gentamycin, ciprofloxacin and Kanamycin (except Staph..aureus) were the most effective antibiotics as 80 to $100 \%$ of the total isolates were found to be susceptible. Because these drugs were the least frequently used in the study area in Veterinary services. Thus no more resistance was developed. Similar suggestion was given by Bedada BA..$^{33}$ The resistance of most of the pathogens to penicillin may be attributed to the production of beta lactamase, an enzyme that inactivates penicillin and closely related antibiotics. It is believed that around $50 \%$ of mastitis causing S. Aureus strains produce beta lactamase. ${ }^{34}$ In that the development of antibiotic resistance is nearly always as a result of repeated therapeutic use and/or indiscriminate usage them. In comparable with the findings of Mekonnen $\mathrm{H}^{5}$ E. Coli was highly resistant to penicillin and streptomycin but highly susceptible to chloramphenicol due to its infrequent. ${ }^{36-39}$

\section{Conclusion and recommendations}

High incidence of heifer mastitis especially occurs as a subclinical type and in high milk producing breeds and older age groups in this area. $S$. aureus and $S$. agalactiae have been identified as the predominant causes of heifer mastitis in the study area, but
Coagulase-negative staphylococci and environmental pathogens were also play a significant role. Some risk factors associated with heifer mastitis have been identified. Fly control, maintaining a clean and comfortable environment, tick infestation, milking practice, and proper hygiene in general are probably the most important factors. Most frequently used drugs were obtained resistance by different isolates. Recoveries of infected quarters were lower. The study also revealed that Staphylococcus. Aureus, Escherichia coli, and Streptococcus agalactiae were highly incident at calving. Based on the above conclusion the following recommendations are forwarded: Farmers education on basic animal health with emphasis on diligent management like milking and housing hygiene and early attention to heifers prepartum udder health which are essential for control and prevention of heifer mastitis that will merit the dairy farms. Further investigation, on heifer subclinical mastitis economic impact on dairy farms and treatment regimen trials and further studies on mastitis causing pathogen at molecular level and their association with potential risk factors is recommended.

\section{Acknowledgements}

This research was supported by the staff of School of Veterinary Medicine, Wolaita Sodo University and I would like to thank the all. I would also like to express my gratitude and appreciate to the personnel of the Bacteriology unit at the Addis Ababa university college of veterinary medicine and agriculture laboratory. All are acknowledged for their willingness cooperation, technical assistance, moral support and helpful encouragement in my graduate study

\section{Declaration and financial support}

I declare that this article (Msc Thesis) presents the work carried out by myself and other co- authors without any financially support. Authors declare that this article presents the work carried out by them self and It does not contain any materials previously published or written by another person except where due reference is made in the text; all substantive contributions by others to the work presented including jointly authored publications, is clearly acknowledged.

\section{Conflict of interest}

The authors confirm you that there is no any conflict of interest.

\section{References}

1. Bitew M, Tafere A, T Tolosa. Study on Bovine mastitis in dairy farms of Bahirdar and its environs. J Animal and Veterinary Advances. 2010;9(23):2912-2917.

2. Fox LK, Chester ST, Hallberg JW, et al. Survey of intramammary infections in dairy heifers at breeding age and first parturition. $J$ Dairy Sci. 1995;78(7):1619-1628.

3. Fox LK. Prevalence, incidence and risk factors of heifer mastitis. Vet Microbiol. 2009;134(1-2):82-98.

4. Piepers S, de Vliegher S, de Kruif A, et al. Impact of intramammary infections in dairy heifers on future udder health, milk production, and culling. Vet Microbiol. 2009;134(1-2):113-120.

5. Mekonnen H, Workineh S, Bayleyegne M, et al. Antimicrobial susceptibility profile of mastitis isolates from cows in three major Ethiopian dairies. Med Vet. 2005;156(7):391-394.

6. Piepers S, De Vliegher S, de Kruif A, et al. Evolution of quarter milk somatic cell counts of dairy heifers in early lactation. Proc. 46th Ann. NMC Meeting, San Antonio, TX, USA; 2007. p. 24-27. 
7. Nibret M, Yilikal A, Kelay B, et al. A antimicrobial Susceptibility of Mastitis Pathogens from Smallholder Dairy Herds in and Around Gondar, Ethiopia. J Anim Vet Adva. 2011;10(12):1616-1622.

8. Siraj A, Getachew T, Tesfaye Sisay, et al. Bacterial Pathogens and Udder Infection Dynamics During the Early Lactation Period in Primiparous Cows in Ambo Town, Central Ethiopia. Global Veterinaria. 2012;8(4):403-408.

9. Williamson J. Dry period and heifer mastitis role of internal and external sealants. Proc. De Laval Symposium, Kansas City, USA; 2002:91-99 p.

10. Quinn PJ, Carter ME, Markey BK, et al. Mastitis in Clinical Veterinary Microbiology. London: Mosby international Limited; 1994. p. 327-344.

11. Quinn PJ, ME Carter, BK Markey, et al. Clinical Veterinary microbiology. Virginia: Harcourt publishers; 2002. p. 331-344.

12. GVA (German Veterinary Association). Leitlinien zur Bekämpfung der Mastitis des Rindes als Herdenproblem. In: Sachverständigenausschuss: Subklinische Mastitis“. DVG, Gießen. 2002.

13. National Committee for Clinical Laboratory Standards. Performance standards for antimicrobial susceptibility testing, 7th informational supplement. Approved standard. 2011;M100-S21.

14. Thrusfield M. Veterinary Epidemiology. 3rd ed. UK: Blackwell science Ltd; 2005. p. 233-250.

15. Pankey JW, Drechsler PA, Wildman EE. Mastitis prevalence in primigravid heifers at parturition. J Dairy Sci. 1991;74(5):1550-1552.

16. Roberson JR, Fox LK, Hancock DD, et al. Coagulase positive Staphylococcus intramammary infections in primiparous dairy cows. $J$ Dair Sci. 1994;77(4):958-969.

17. Barkema HW, Schukken YH, Lam TJ, et al. Incidence of clinica mastitis in dairy herds grouped in 3categories by bulk milk somatic cell counts. J Dairy Sci. 1998;81(2):411-419.

18. Oliver SP. Frequency of isolation of environmental mastitis causing pathogens and Incidence of new intramammary infection during the nonlactating period. Am J Vet Res. 1988;49(11):1789-1793.

19. Trinidad P, Nickerson SC, Adkinson RW. Histopathology of staphylococcal mastitis in unbreed dairy heifers. $J$ Dairy Sci. 1990;73(3):639-647.

20. Wathes DC, Cheng Z, Bourne N, et al. Differences between primiparous and multiparous dairy cows in the inter relationships between metabolic traits, milk yield and body condition score in the periparturient period. Domest Anim Endocrinol. 2007;33(2):203-225.

21. Bassel L, Kelton D, Godkin A, et al. Risk factors for intramammary infection at first calving in Ontario dairy heifers. Proc. 36th Ann. Conv. Columbus: AABP; 2003. p. 177-178

22. Giraudo JA, Calzolari A, Rampone $\mathrm{H}$, et al. Field trials of vaccine against bovine mastitis. Evaluation in heifers. J Dairy Sci. 1997;80(5):845-853.
23. Nickerson SC, Owens WE, Boddie RL. Mastitis in dairy heifers: Initial studies on prevalence and control. J Dairy Sci. 1995;78(7):1607-1618.

24. Owens WE, Nickerson SC, Washburn PJ, et al. Prepartum antibiotic therapy with a cephapirin dry cow product against naturally occurring intramammary infections in heifers. Vet Med. 1993;41(2):90-100.

25. Sori H, A Zerihum, S Abdicho. Dairy cattle mastitis in and around Sebeta, Ethiopia. Int J Appl Res Vet Med. 2005;3(4):332-338.

26. Oliver SP, Gillespie BE, Headrick SJ, et al. Heifer mastitis: prevalence, risk factors and control strategies. J Am Vet Med. 2004. p. 114-121.

27. Radostits OM, Leslie KE, Fetrow J. Herd Health: Food Animal Production Medicine. 2nd ed. Toronto, USA: W.B. Saunders Company; 1994. p. 229-273.

28. Compton CW, Heuer C, Parker K, et al. Epidemiology of mastitis in pasture-grazed peripartum dairy heifers and its effects on productivity. J Dairy Sci. 2007;90(9):4157-4170.

29. Almaw G, Zerihun A, Asfaw Y. Bovine mastitis and its association with selected risk factors in smallholder dairy farms in and around Bahir Dar, Ethiopia. Trop Anim Health Prod. 2008;40(6):427-432.

30. Argaw K, Tolosa T. Prevalence of subclinical mastitis in small holder dairy farms in Selale, North Shewa Zone, Central Ethiopia. The Internet $J$ Veterinary Medicine. 2008;5(1):1-5.

31. Mekbib B, M Furgasa, F Abunna, et al. Bovine Mastitis: Prevalence, risk factors and major pathogens in dairy farms of Holeta town, Central Ethiopia. Veterinary World. 2010;3(9):397-403.

32. Lakew M, Tolosa T, Tigre W. Prevalence and major bacterial causes of Bovine mastitis in Assela, South Eastern Ethiopia. Tropical Animal Health and Production. 2009;4:1525-1530.

33. Bedada BA, Hiko A. Mastitis and antimicrobial susceptibility test. $J$ Microbiology and Antimicrobials. 2011;3:228-232.

34. Bradley AJ. Bovine mastitis: an evolving disease. Vet $J$. 2002;164(2):116-128.

35. Tariku S, Jemal H, Mollalegn B. Prevalence and susceptibility Assay of Staphylococcus aureusisolated from bovine mastitis in dairy farms of Jimma Twon, south west Ethiopia. J Anim Vet adv. 2011;10(6):745-749

36. Owens WE, Oliver SP, Gillespie BE, et al. Role of horn flies (Haematobia irritans) in Staphylococcus aureus induced mastitis in dairy heifers. Am J Vet Res. 1998;59(9):1122-1124.

37. Quinn PJ, Carter ME, Markey BK, et al. Clinical Veterinary Microbiology. London, UK: Mosby; 1999:21-66 p.

38. Radostits OM, Gay CC, Hinchcliff KW. Veterinary Medicine. 10th ed Saunders: Elsevier, 2007. p. 673-762.

39. McDougall S, Parker KI, Heuer C, et al. A review of prevention and control of heifer mastitis via non-antibiotic strategies. Vet Microbiol. 2009;134(1-2):177-185. 